\title{
Evaluation of Water Treatment Systems for Medical Clinics
}

\author{
Phillip L. Thompson \\ Civil \& Environmental Engineering \\ Seattle University \\ Seattle, WA 98122 \\ thompson@seattleu.edu \\ Amanda A. Connell \\ Civil \& Environmental Engineering \\ Seattle University \\ Seattle, WA 98122 \\ amandaanneconnell@gmail.com \\ David L. Jacobs, Jr. \\ Seattle Public Utilities \\ Drainage \& Wastewater Division \\ Seattle, WA 98124 \\ dave.jacobs@seattle.gov
}

\author{
Chris R. Kemly \\ Civil \& Environmental Engineering \\ Seattle University \\ Seattle, WA 98122 \\ chriskemly@gmail.com \\ Kathryn V. Nolan \\ Civil \& Environmental Engineering \\ University of Colorado \\ Boulder, CO 80027 \\ kathryn.nolan@Colorado.edu \\ Gerald Omar A. Ongoco \\ Civil \& Environmental Engineering \\ Seattle University \\ Seattle, WA 98122 \\ gongoco@gmail.com
}

Abstract - A Seattle University senior engineering design team evaluated the treatment performance of a point-of-use microfiltration-ultraviolet light (MF-UV) drinking water treatment system and of an ultrafiltration (UF) unit. The MF-UV system reduced turbidity by 70 percent and inactivated 100 percent of E.coli from model water. The UF system removed 100 percent of all turbidity and bacteria. The combined MF-UF-UV treatment system can provide up to 33,120 liters of water per day and meet basic human water needs at an annual cost of approximately US\$0.80 per capita. To maintain safe water quality during transport and storage, on-site generated chlorine can be added to the MF-UF-UV treated water. The team evaluated the performance of a chlorine generator and confirmed that chlorine testing strips were excellent surrogates for the N,N-diethyl-pphenylenediamine (DPD) colorimetric method. Public-private partnerships may be required to ensure long-term sustainability of these drinking water treatment systems in the developing world.

Index Terms - microfiltration, ultrafiltration, chlorine, UV disinfection, drinking water

\section{INTRODUCTION}

In September 2010, the United Nations reported that 884 million people around the world still lacked access to an improved source of drinking water ${ }^{1}$. The World Health Organization (WHO) considers boreholes, piped connections, protected springs, public standpipes and rainwater collection systems as improved water sources ${ }^{2}$. Quantifying the number of improved water sources is a surrogate measure for access to safe water, because water quality data is limited. However, improved sources are not necessarily safe, and the actual number of people without safe water is likely much higher than reported ${ }^{3}$. One such example is the village of Mae Nam 
Khun (MNK), Thailand which has a population of approximately 5000 people and is located in the mountains along the Myanmar border ${ }^{4}$. The water supply for the village is untreated stormwater that is piped from a man-made reservoir. The reservoir is elevated approximately 100 meters above the village, and it is subject to contamination from livestock and other animals.

In July 2006, Seattle University's Engineers Without Borders-USA student chapter (SUEWB) completed construction of a dormitory and sanitation facilities for a boarding school in MNK. After water quality testing of the dormitory water supply revealed high levels of coliform bacteria, SU-EWB installed a point-of-use microfiltration-ultraviolet light (MF-UV) drinking water treatment system for the dormitory in August 2007 (Figure 1). The treatment process begins with a reusable 50-micron bag filter followed by a 5-micron string-wound polypropylene fiber filter. After dissolved organic compounds are removed by an activated carbon filter, the water is disinfected by ultraviolet (UV) light. The initial material costs were approximately $\$ 1500^{4}$. The system required a water pressure of approximately $15 \mathrm{psi}$ and $30 \mathrm{~W}$ to power the UV lamp, both of which were readily available in $\mathrm{MNK}^{4}$.

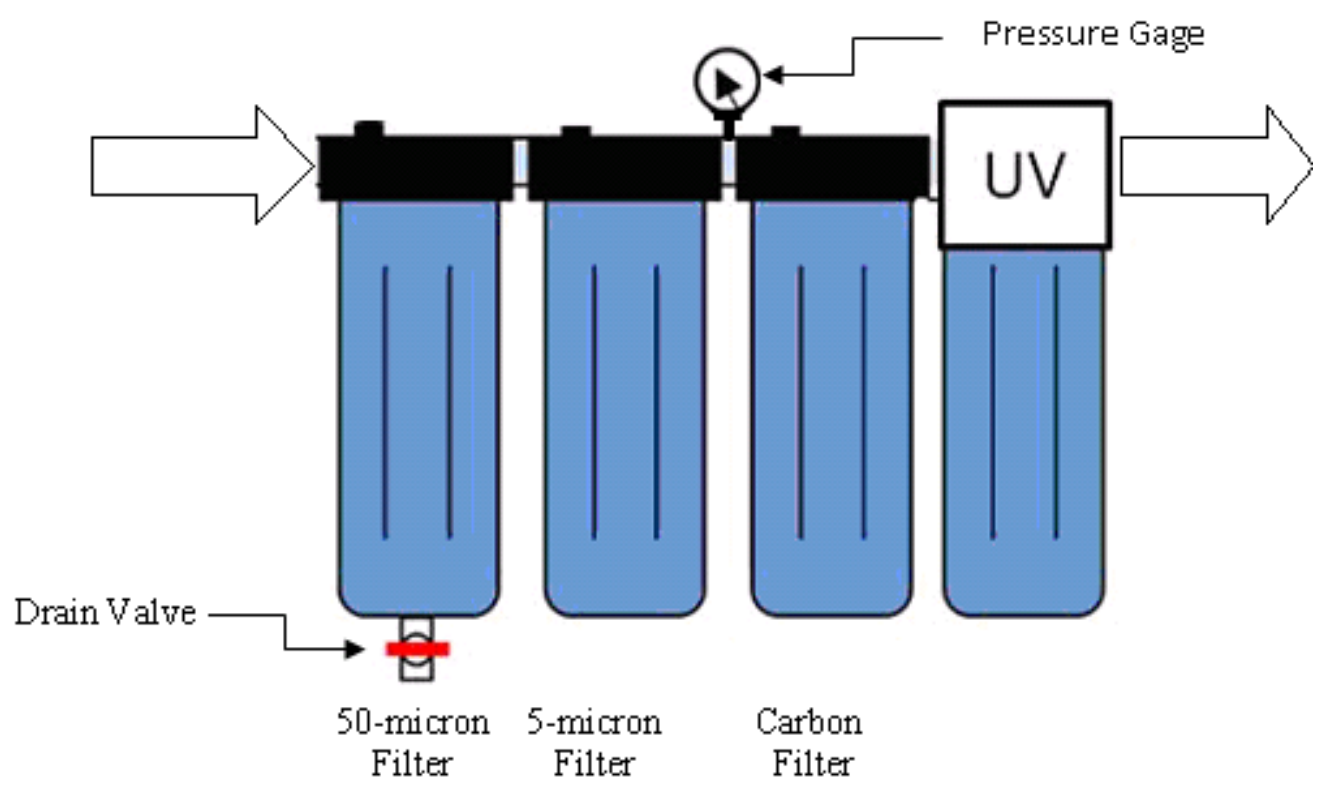

FIGURE 1

\section{DORMITORY MICROFILTRATION-ULTRAVIOLET LIGHT DISINFECTION WATER TREATMENT SYSTEM}

The MF-UV treatment alternative was selected because it was 1) capable of producing up to 21,000 liters per day for the 60 residents of the dormitory 2) cost effective and 3) supported by locally available replacement materials and maintenance experts ${ }^{4}$. Similar treatment systems have also been deployed by others for projects in the developing world ${ }^{5,6,7}$. The strategy of one of these groups is to work collaboratively to maintain the systems with the community for up to twenty years 6 .

After 30 months of operation, an additional treatment system was installed for the MNK medical clinic upon the director's request. This provided access to a safe water source for the broader community, and enabled the clinic to produce significantly more water per day (e.g. 
thousands of liters compared to tens of liters). The on-going maintenance costs (approximately $\$ 350$ per year $^{4}$ ) for each system have been met by donations that are received by the clinic and dormitory. The clinic staff is also exploring a future fee structure for significant users of the system (e.g. US\$1 per 100 liters).

Students from Chiang Mai University's civil engineering department have performed routine water quality monitoring since 2007. The raw water for both treatment systems has consistently had coliform concentrations in the range of 100 to $200 \mathrm{cfu}$ per 100-ml. Coliform concentrations for the treated water have ranged from non-detect to $5 \mathrm{cfu}$ per 100-ml (Figure 2). It was hypothesized that breakthrough was occurring because bacteria were being shielded by colloidal particles that were passing through the 5-micron filter.

Since this field performance fell short of the water quality goal of zero coliform, a Seattle University senior engineering design team of four civil engineering majors was tasked with testing the treatment system in the laboratory and evaluating the removal of turbidity and bacteria. The team also had the objectives of evaluating 1) the addition of ultrafiltration to the treatment process and 2) the performance of a chlorine generator. Ultrafiltration was chosen because it is capable of removing submicron particles including bacteria and viruses. The chlorine generator performance was evaluated so that users of the treatment system could consistently add a chlorine residual for safe storage of the treated water.

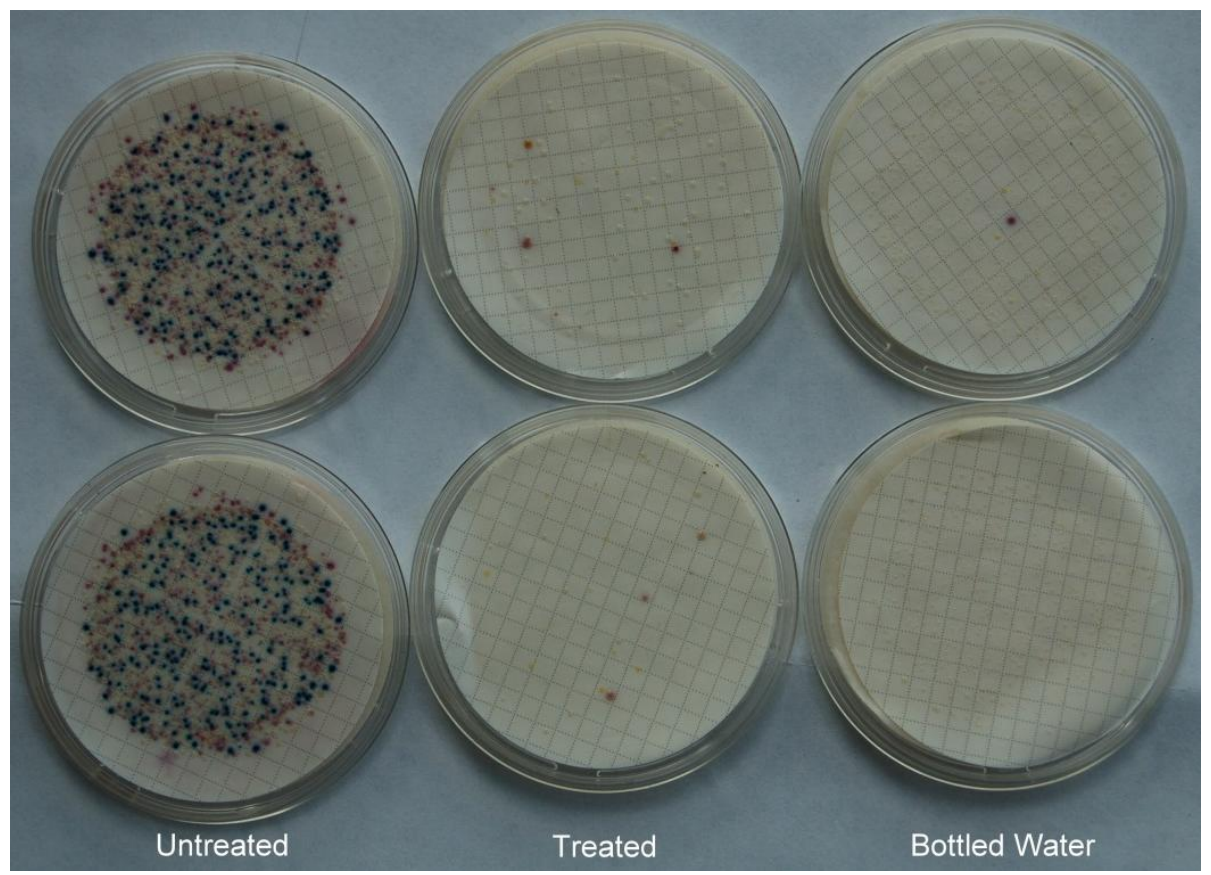

FIGURE 2

THE WATER TREATMENT SYSTEM SIGNIFICANTLY REDUCED COLIFORM (PINK) AND ESCHERICHIA COLI (BLUE) BACTERIA, HOWEVER 100 PERCENT REMOVAL HAS NOT ALWAYS BEEN ACHIEVED.

The chlorine generator could also be used by clinics that implement the Centers for Disease Control and Prevention's Safe Water System (SWS) ${ }^{8}$. The SWS is a community-level chlorine distribution program that is practiced by millions of worldwide users for household-level 
drinking water treatment. After filtering their water with a sand or clay pot filter, users can disinfect their water for use and storage. At an annual cost of US\$0.50 per capita, the WHO has identified the SWS as the most cost-effective approach to safe water access for the developing world ${ }^{9}$.

\section{MATERIALS AND METHODS}

\section{Treatment System Setup}

The laboratory treatment system (Figure 3) was assembled in series with a 50-micron bag filter, 5-micron string-wound polypropylene fiber filter, a carbon filter and a Pentair UV unit (Model BB-120-1) with a UV dose of $16 \mathrm{~mJ} / \mathrm{cm}^{2}$, each of which were enclosed in 20-inch long, 4.5 inch diameter housings. All filters and UV bulbs were manufactured by Pentair Water (Milwaukee, WI, USA). A Pentair Freshpoint U440 ultrafiltration (UF) unit (0.06 $\mu \mathrm{m}$ absolute pore size) was installed prior to the UV unit during turbidity removal tests. Each system component was fitted with a $3 / 4$-inch brass faucet for sampling and was connected with a 1 -inch diameter PVC pipe, a 1-inch diameter flexible stainless steel pipe, or a 3/4-inch stainless steel hoses. The total emptybed volume of the treatment system was approximately $20-\mathrm{L}$.

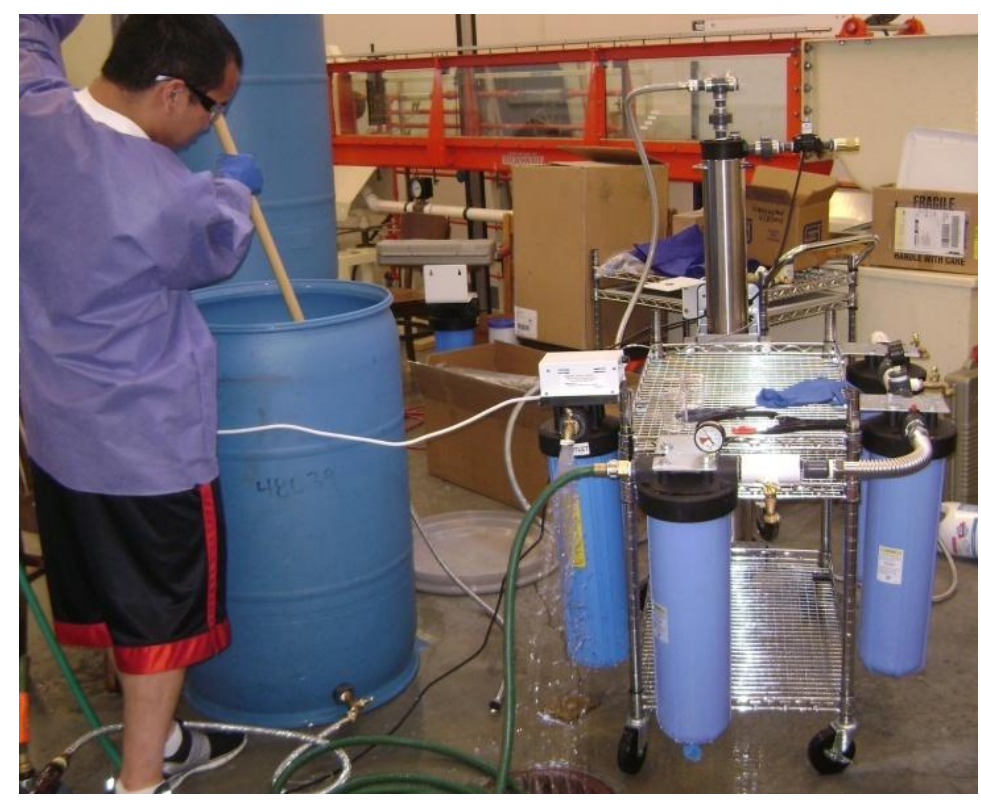

FIGURE 3

THE LABORATORY WATER TREATMENT SYSTEM WAS EQUIPPED WITH SAMPLING PORTS FOR EACH STAGE OF TREATMENT.

\section{Model Water Preparation}

A 208-L water barrel was filled with tap water from the City of Seattle. The tap water was dechlorinated with an activated carbon filter. To mimic the water turbidity of the clayey soil in MNK, approximately 125 grams of kaolinite clay was mixed into the water barrel and settled over a 24-hour period. The supernatant was transferred to another 208-L barrel using a faucet located three inches from the bottom of the settling barrel as an outlet source. The transfer barrel 
was then replenished with de-chlorinated water to account for the volume lost during the decanting process.

Escherichia coli (E. coli) was added to the model water to mimic bacterial contamination. A stock solution of E. coli strain ATCC 25922 (Fisher Scientific, Houston, TX, USA) was prepared for use throughout laboratory testing. Difco-m Endo Broth MF (Fisher Scientific, Houston, TX, USA) substrate was prepared, diluted 100-fold and used as a growth medium. The E. coli solution was then placed in a New Brunswick Scientific Excella E24 Incubator Shaker (Edison, NJ, USA) and grown at $35^{\circ} \mathrm{C}$ while being agitated at 150 cycles per minute for 18 - 24 hours. The $E$. coli culture was grown to an initial concentration of approximately $10^{9} \mathrm{CFU}$ per ml. Then $2.10-\mathrm{ml}$ of $E$. coli stock solution was mixed with the $208-\mathrm{L}$ of model water to produce an $E$. coli concentration in the range of $10^{5} \mathrm{cfu}$ per $\mathrm{ml}$. Over time, the stock solution reached a concentration of $10^{18}$ which required dilution adjustments during sample analysis.

The model water was fed to the treatment system by connecting a $3 / 4$-in hose to the continuously-stirred water barrel and to a Utilitech 1-horsepower portable lawn pump (West Lawn, PA, USA, Model \#0024840). After pumping 60-L of model water through the system (3 control volumes), samples were collected from each sample port in duplicate with 700-ml sterile bottles and immediately analyzed for turbidity and $E$. coli.

\section{Sample Analysis}

Turbidity was measured with a Hach 2100A nephelometric turbidimeter (Hach Company, Loveland, CO, USA). The turbidimeter had a detection limit of 2 NTU and was calibrated with an accompanying 100 NTU Geltex standard. Each water sample was analyzed in triplicate.

Samples were tested in triplicate for E. Coli by using the Coliscan Membrane Filtration (MF) technique (Micrology Laboratories, Goshen, IN, USA). Dilutions of $10^{-5}, 10^{-8}$ and $10^{-9}$ were prepared for the untreated samples and those from the 50-micron, 5-micron, and activated carbon filters. Samples from the UF unit and UV system were not diluted. Petri dishes were stored in an incubator at $35^{\circ} \mathrm{C}$ for 24-hours and then counted.

The N,N-diethyl-p-phenylenediamine $(D P D)$ colorimetric method ${ }^{10}$ was used for chlorine analysis. Chlorine concentrations were also measured with commercially manufactured SenSafe (Rockhill, SC, USA) chlorine test strips. All chlorine samples were analyzed in duplicate and were diluted to less than $6 \mathrm{mg} / \mathrm{L}$ as $\mathrm{Cl}_{2}$ to fall within the detection range of both methods. The $\mathrm{pH}$ of chlorine solutions was measured with a Beckman $\Phi 32 \mathrm{pH}$ meter (Brea, CA, USA).

\section{Chlorine Generation}

Two BrightSpark 2B Safe chlorine generators (Joure, Netherlands) were tested in order to establish the expected concentration and precision of chlorine generation. BrightSpark (formerly DipCell) was one of four chlorine generator manufacturers that were recommended by the CDC for its SWS community program ${ }^{11}$. Chlorine stock solutions were prepared by adding 34.5 grams of sodium chloride (Fisher Scientific, Houston, TX, USA) to 11.5 liters of de-chlorinated tap water stored in a three gallon amber carboy (Fisher Scientific, Houston, TX, USA). The chlorine generator was placed into the carboy and electrolysis lasted for up to 24-hr. 


\section{RESULTS AND DISCUSSION}

\section{Turbidity Removal}

Table I shows typical turbidity removal results for the water treatment system. The 50-micron bag filter did not significantly remove turbidity, and there was significant breakthrough of turbidity for both the 5-micron and activated carbon filters (Figure 4). These results demonstrated that the shielding of bacteria from UV disinfection by colloidal particles could be expected for the treatment systems in MNK. It is also possible that continuous breakthrough of small particles could contribute to coating the quartz sleeve of the UV bulb which would reduce the intensity of the UV dose. The results also demonstrated that the UF unit was consistently capable of removing all measurable turbidity.

\section{TABLE I}

TURBIDITY RESULTS FROM CONTROL, 50- $\mu$ M FILTER, 5- $\mu$ M FILTER, ACTIVATED CARBON FILTER, AND UltRAFILTRATION UNIT. All VALUES ARE NTU, ND=NOT DETECTABLE.

\begin{tabular}{cccccc}
\hline & $\begin{array}{c}\text { Control } \\
(\mathbf{N T U})\end{array}$ & $\begin{array}{c}\mathbf{5 0} \boldsymbol{\mu m} \\
(\mathbf{N T U})\end{array}$ & $\begin{array}{c}\mathbf{5} \boldsymbol{\mu m} \\
(\mathbf{N T U})\end{array}$ & $\begin{array}{c}\text { AC } \\
(\mathbf{N T U})\end{array}$ & $\begin{array}{c}\text { UF } \\
(\mathbf{N T U})\end{array}$ \\
\hline Average $(\mathbf{N}=\mathbf{4})$ & 53 & 51 & 37 & 15 & ND \\
Standard Deviation & 4 & 1 & 4 & 3 & \\
\hline
\end{tabular}

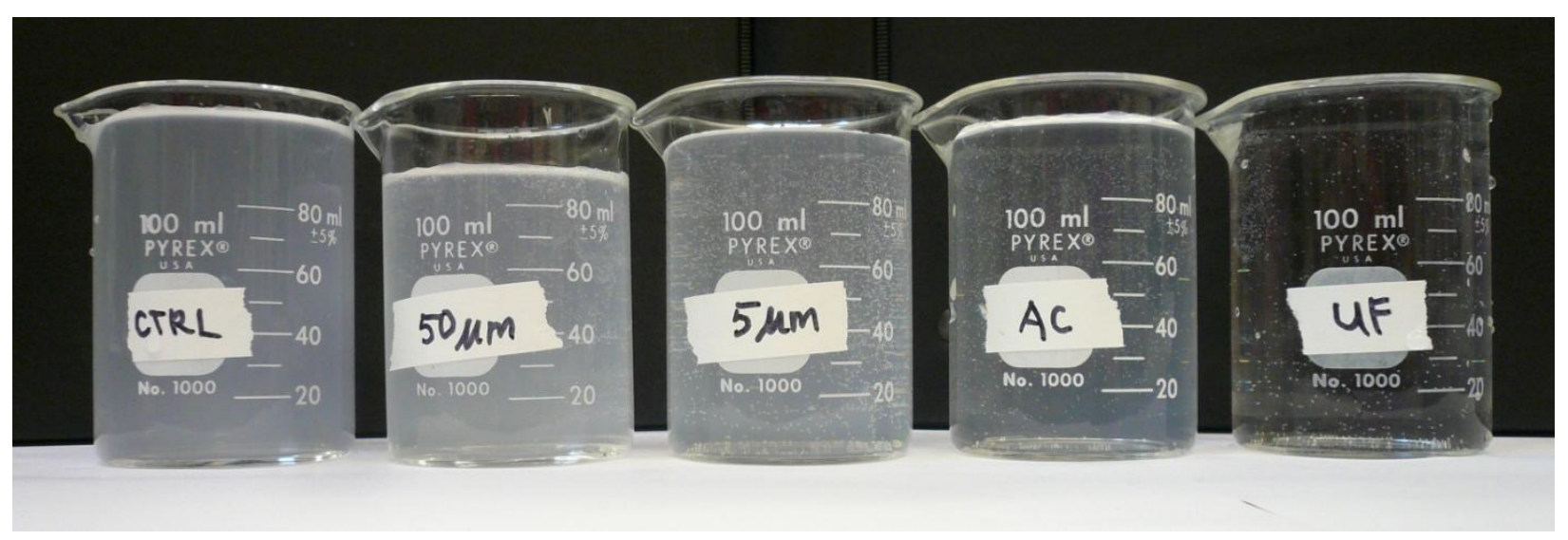

FIGURE 4

TURBIDITY COMPARISON FOR CONTROL AND SAMPLES TREATED WITH A 50- $\mu$ M FILTER, 5- $\mu \mathrm{M}$ FILTER, ACTIVATED CARBON FILTER, AND ULTRAFILTRATION UNIT.

\section{E. Coli Inactivation}

Table II summarizes the data for the inactivation of E.coli by the treatment system without the UF unit installed. Despite 30 percent of the initial kaolinite clay particles being present, the UV unit was still capable of completely inactivating the bacteria. As expected, there was no significant removal of E.coli by any of the filters prior to the UV. 
After testing the original system configuration, the UF unit was installed between the AC filter and UV unit. The system was run for five minutes to approach a steady state flow. Despite letting the system run, the connection between the UF and UV units was contaminated from the previous test. This allowed bacteria to be detected after the UF unit which was not expected (data not shown). To prove that contamination of the pipe fitting caused the positive bacteria measurement, model water was directly pumped through the UF unit without pretreatment. As expected, the UF was able to achieve a $100 \%$ removal of $E$. coli (and turbidity) due to the 0.06 micron absolute pore size (Table III).

TABLE II

E.COLI COUNTS PER 100-ML SAMPLE FROM CONTROL, 50- $\mu$ M FILTER, 5- $\mu$ M FILTER, ACTIVATED CARBON FILTER, AND ULTRAVIOLET LIGHT. ALL VALUES ARE CFU. $\mathrm{N}=4$ FOR EACH SAMPLE, ND=NOT DETECTABLE.

\begin{tabular}{lccccc}
\hline & Control & $\mathbf{5 0} \boldsymbol{\mu m}$ & $\mathbf{5} \boldsymbol{\mu m}$ & $\mathbf{A C}$ & $\mathbf{U V}$ \\
\hline Average & $3.2 \mathrm{E}+10$ & $3.6 \mathrm{E}+10$ & $3.2 \mathrm{E}+10$ & $2.5 \mathrm{E}+10$ & $\mathrm{ND}$ \\
Std. Dev. & $1.4 \mathrm{E}+09$ & $2.1 \mathrm{E}+09$ & $9.2 \mathrm{E}+09$ & $2.8 \mathrm{E}+09$ & \\
\hline
\end{tabular}

TABLE III

E.COLI COUNTS PER 100-ML SAMPLE FROM CONTROL, AND ULTRAFILTRATION UNIT ALL VALUES ARE CFU. $\mathrm{N}=4$ FOR EACH SAMPLE. , ND=NOT DETECTABLE.

\begin{tabular}{ccc}
\hline & Control & UF \\
\hline Average & $2.2 \mathrm{E}+09$ & $\mathrm{ND}$ \\
Std. Dev. & $4.4 \mathrm{E}+08$ & \\
\hline
\end{tabular}

\section{Chlorine Generation}

The DPD colorimetric method is a commonly used method for the measurement of chlorine concentrations. However, since the DPD method may not be practical for measuring chlorine concentrations in the field, chlorine test strips were tested. Table IV compares the two methods and indicates that there was an average percent difference of less than one percent. The relative standard deviation (RSD) for each method was consistently less than five percent. These results confirmed that the test strips would be excellent for use in the field and could produce reliable results for chlorine measurement. 
TABLE IV

COMPARISON OF DPD METHOD TO SENSAFE CHLORINE TEST STRIPS. EACH TRIAL REPRESENTS THE AVERAGE OF A DUPLICATE MEASUREMENT. ALL CALCULATED VALUES ARE MG/L AS $\mathrm{CL}_{2}$.

\begin{tabular}{ccc} 
Trial & DPD Method & Test Strips \\
\hline 1 & 1255 & 1200 \\
2 & 1130 & 1200 \\
3 & 1190 & 1200 \\
4 & 1300 & 1200 \\
5 & 1210 & 1200 \\
6 & 1170 & 1200 \\
\hline Average & 1208 & 1200 \\
Standard Deviation & 52 & 0 \\
\hline
\end{tabular}

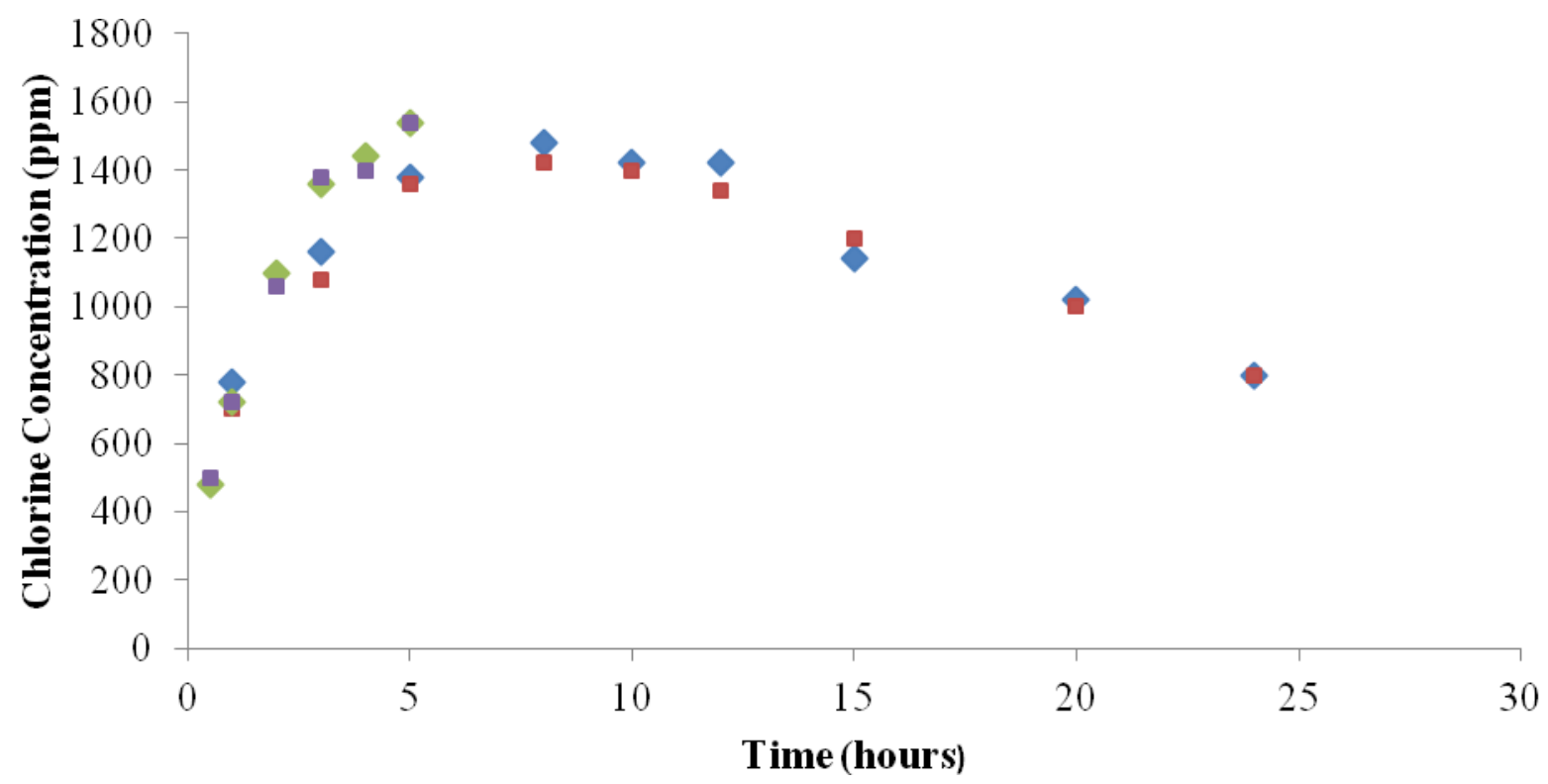

FIGURE 5

CHLORINE PRODUCTION OVER TIME WITH TWO BRIGHTSPARK 2B SAFE GENERATORS. 


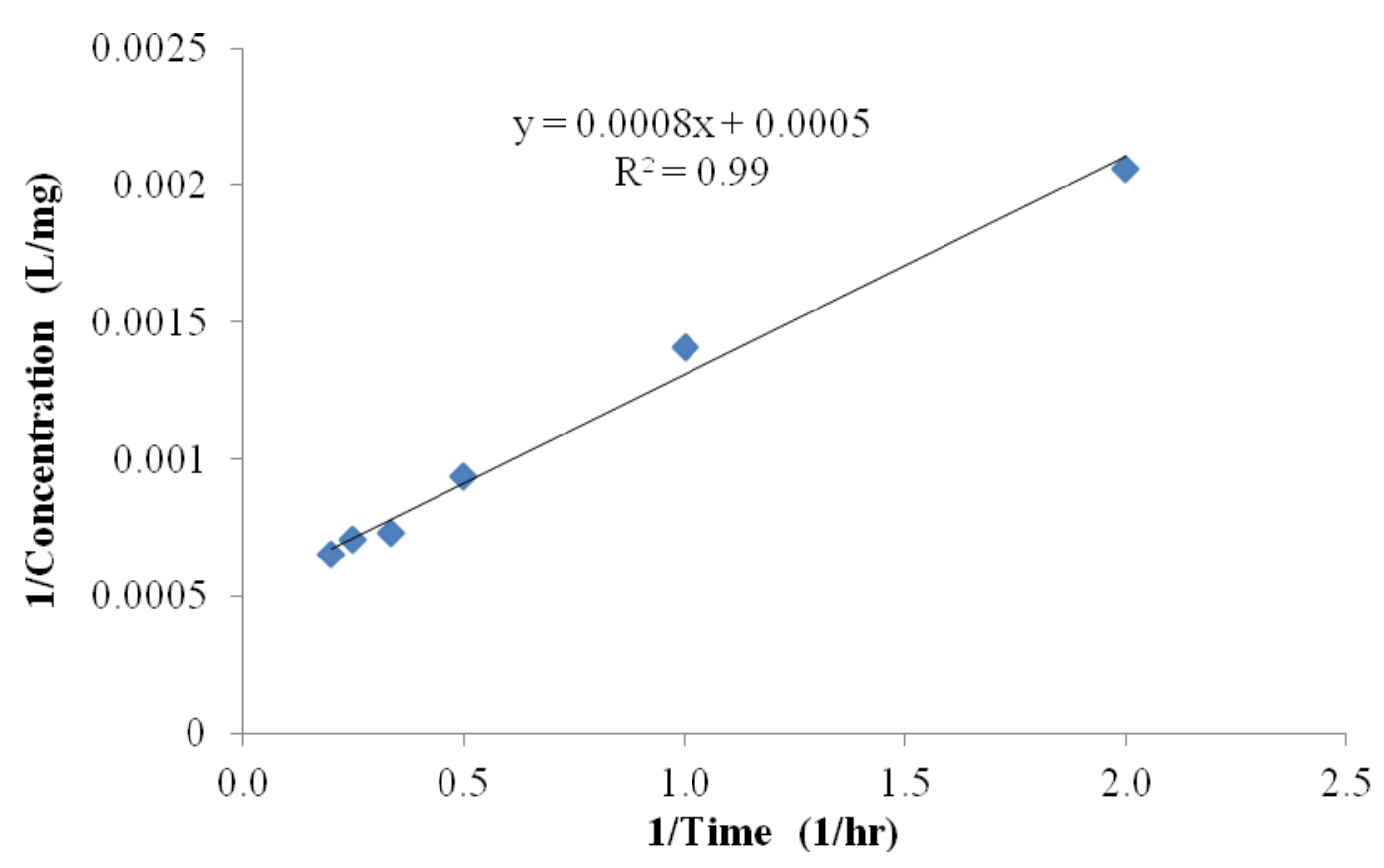

FIGURE 6

A SECOND-ORDER CHLORINE PRODUCTION RATE WAS ESTIMATED TO BE $0.0008 \mathrm{LITER} \cdot \mathrm{MG}^{-1} \cdot \mathrm{HR}^{-1}$ FOR THE BRIGHTSPARK $2 \mathrm{~B}$ SAFE CHLORINE GENERATOR.

Figure 5 illustrates the 24 hour generation curve of the two generators tested in parallel. The tests indicated that chlorine generation peaks between 5 and 10 hours and then starts to decline the longer the generators are run. These results established that the generators should be run for no more than 10 hours in order to maximize chlorine production. The decline in concentration after 10 hours was likely due to the dissociation of chlorine that resulted from electrolysis reactions within the highly oxidizing environment ${ }^{12}$. A second-order chlorine production rate was estimated to be 0.0008 liter $\cdot$ hour $\cdot \mathrm{mg}^{-1}$ (Figure 6).

Chlorine concentrations from each BrightSpark 2B Safe chlorine generator were measured to determine if the generators could produce consistent concentrations. A series of ten 12-hour trials (Table V) indicated that each of the chlorine generators consistently produced approximately $1200 \mathrm{mg} / \mathrm{L}$ as $\mathrm{Cl}_{2}$ with an RSD of approximately five percent for each generator. At this concentration, each 11.5 -L batch of chlorine could disinfect 23,000 liters of water with a residual of $0.6 \mathrm{mg} / \mathrm{L}$ as $\mathrm{Cl}_{2}$. The $\mathrm{pH}$ of the chlorine batches ranged from 9.9 to 10.3 . 
TABLE V

AFTER 12-HOURS OF OPERATION, THE BRIGHTSPARK 2B SAFE CHLORINE GENERATOR WAS CAPABLE OF GENERATING CONSISTENT CHLORINE CONCENTRATIONS. EACH VALUE REPRESENTS THE AVERAGE OF A DUPLICATE MEASUREMENT. ALL CALCULATED VALUES ARE MG/L AS CL2.

\begin{tabular}{ccc} 
Trial & Generator 1 & Generator 2 \\
\hline 1 & 1250 & 1290 \\
2 & 1110 & 1150 \\
3 & 1180 & 1200 \\
4 & 1280 & 1320 \\
5 & 1240 & 1180 \\
6 & 1140 & 1200 \\
7 & 1210 & 1280 \\
8 & 1150 & 1300 \\
9 & 1150 & 1140 \\
10 & 1190 & 1230 \\
\hline Average & 1190 & 1229 \\
Standard Deviation & 55 & 65 \\
\hline
\end{tabular}

\section{Economic Analysis}

Table VI summarizes the initial cost and the annual operation and maintenance costs for the combined MF-UF-UV system. The start-up cost for the system includes all components of the treatment system and one year of replacement filters. The annual maintenance costs include an annualized cost for replacing the UF membrane which is expected to have a five-year useful life. Assuming a four percent annual rate of inflation, these materials have a net present value of $\$ 6,796$. Since the UF unit produces approximately 23 LPM on a continuous basis or a maximum of 33,120 liters per day, the cost over five years is approximately US\$0.11 per 1000 liters of water. The WHO estimates that 20 -L of water per day are needed to meet basic human needs ${ }^{2}$, so excluding power and labor, the annual per capita cost of producing safe water with the UF treatment system is approximately US\$0.80. 
TABLE VI

THE PRESENT WORTH OF THE INITIAL AND MAINTENANCE COSTS FOR AN ULTRAFILTRATION DRINKING WATER SYSTEM CONTINUOUSLY OPERATING AT 23 LITERS PER MINUTE WITH A FOUR PERCENT ANNUAL INFLATION RATE. ALL COSTS ARE IN US\$.

\begin{tabular}{|c|c|c|c|c|c|c|c|c|c|c|c|}
\hline \multirow{2}{*}{$\begin{array}{c}\text { Year } \\
0\end{array}$} & \multirow{2}{*}{\multicolumn{2}{|c|}{$\frac{\mathbf{U F}}{\$ 1,300}$}} & \multicolumn{2}{|c|}{$50-\mu m^{*}$} & \multicolumn{2}{|c|}{$5-\mu m^{* * *}$} & \multicolumn{2}{|c|}{$\mathbf{A C}^{* * * *}$} & \multirow{2}{*}{\multicolumn{2}{|c|}{$\frac{\mathbf{U V}}{\$ 500}$}} & \multirow{2}{*}{$\frac{\text { Total }}{\$ 2,556}$} \\
\hline & & & $\$$ & 136 & $\$$ & 190 & $\$$ & 430 & & & \\
\hline 1 & $\$$ & 312 & $\$$ & 19 & $\$$ & 125 & $\$$ & 374 & $\$$ & 52 & $\$ \quad 882$ \\
\hline 2 & $\$$ & 324 & $\$$ & 19 & $\$$ & 130 & $\$$ & 389 & $\$$ & 54 & \$ 917 \\
\hline 3 & $\$$ & 337 & $\$$ & 20 & $\$$ & 135 & $\$$ & 405 & $\$$ & 56 & 954 \\
\hline 4 & $\$$ & 351 & $\$$ & 21 & $\$$ & 140 & $\$$ & 421 & $\$$ & 58 & \$ 992 \\
\hline 5 & $\$$ & 365 & $\$$ & 22 & $\$$ & 146 & $\$$ & 438 & $\$$ & 61 & $\$ 1,032$ \\
\hline \multicolumn{12}{|c|}{$\begin{array}{c}\text { Net Present Value }=\$ 6,796 \\
\text { Cost per } 1000-\mathrm{L}=\$ 0.11\end{array}$} \\
\hline
\end{tabular}

\footnotetext{
*6 replacements per year

$* * 8$ replacements per year

$* * * 9$ replacements per year
}

\section{CONCLUSIONS}

The laboratory evaluation of an MF-UV drinking water treatment system revealed that the system was able to remove approximately 70 percent of the turbidity from model water. The breakthrough of submicron particles could either directly shield bacteria from UV exposure or could decrease UV intensity by soiling the lamp's quartz sleeve over time. A UF unit was capable of reducing the turbidity to detection limits. Both the MF-UV and the UF units were able to effectively inactivate and remove 100 percent of all E. coli, respectively. An assembly and operations manual was developed for an MF-UV-UF system ${ }^{13}$. Combining the MF-UV and UF treatment processes can provide a dual barrier of protection against biological contamination.

On-site generated chlorine can provide an additional, cost-effective barrier to biological contamination during storage and transport of water. The BrightSpark 2B Safe chlorine generator produced consistent chlorine concentrations and had an optimum time for operating of approximately 10 hours. A step-by-step protocol for production and chlorine distribution has been developed ${ }^{13}$ to facilitate the establishment of an SWS program and to minimize the overdosing of chlorine which could lead to user dissatisfaction. In addition, SenSafe chlorine test strips were found to be excellent surrogates for the DPD colorimetric chlorine measurement method.

The MF-UF-UV treatment process is highly effective at producing large quantities of safe water on a continuous basis at a cost of approximately US $\$ 0.11$ per 1000 liters or US $\$ 0.80$ per capita per year. However, many organizations are hesitant to implement this type of technology in the developing world because of concerns related to long-term maintenance ${ }^{14}$. To address this issue of sustainability, our strategy is to support public-private partnerships between medical clinics and small businesses within the community ${ }^{4}$ that can provide maintenance for the treatment systems over time. The clinics must generate US\$3 per day to meet the materials cost 
either through their budget or by collecting fees from significant water consumers. These fees can be used to support the maintenance of the water treatment system and other clinic needs.

\section{ACKNOWLEDGMENT}

We thank the Emerald City Rotary Club for providing funding for this project. We also thank Mr. Frederick W. Jiencke III for his expertise in the laboratory.

\section{REFERENCES}

${ }^{1}$ United Nations (2010) "2015 Millennium Development Goals: Goal 7 Fact Sheet” United Nations Summit, New York. http://www.un.org/millenniumgoals/pdf/MDG_FS_7_EN.pdf, Retrieved December 31, 2011.

${ }^{2}$ World Health Organization (2006). Guidelines for Drinking-water Quality First Addendum to Third Edition Volume 1 Recommendations. World Health Organization: Geneva.

${ }^{3}$ Lantagne, Daniele S. Quick, Robert, and Mintz, Eric (2006). "Household Water Treatment and Safe Storage Options in Developing Countries: A Review of Current Implementation Practices" Woodrow Wilson International Center for Scholars, Washington D.C. http://www.wilsoncenter.org/publication/household-water-treatment-and-safe-storage-optionsdeveloping-countries-review-current, Retrieved December 31, 2011.

${ }^{4}$ Thompson, Phillip (2010). "Economically Sustainable Safe Drinking Water Systems for the Developing World”. Business and Society Review. 115(4): 477-493.

${ }^{5}$ Hart, James, MacDonald, Matthew, Montminy, Shaun, Duffy, John (2003). "A Water Purification System for Remote Villages Utilizing Ultraviolet Sterilization and Photovoltaics", Proceedings of the National Solar Energy Conference of the American Solar Energy Society, Austin, TX. http://energy.caeds.eng.uml.edu/Peru/ASES03-A167-water-final.pdf, Retrieved December 31, 2011.

${ }^{6}$ Stowe, Eric (2009). Personal Communication. http://achildsright.org/method/, Tacoma, WA.

${ }^{7}$ Magee, Andrew, Macdonald, Rebecca., Johnson, Pauline., Johnson, Philip, Todd, Beth (2011). "Safe Water Evaluations in the Peruvian Amazon." International Journal for Service Learning in Engineering. 6(1): 104-117.

${ }^{8}$ Centers for Disease Control (2007). Safe Water Systems for the Developing World:

A Handbook for Implementing Household-Based Water Treatment and Safe Storage Projects. http://www.cdc.gov/safewater/sws_pubs.htm, Retrieved December 31, 2011.

${ }^{9}$ Hutton, G., Haller, L. (2004). "Evaluation of the Costs and Benefits of Water and Sanitation Improvements at the Global Level", World Health Organization, Geneva.

${ }^{10}$ American Public Health Association (2005). Standard Methods for the Examination of Water and Wastewater, $21^{\text {st }}$ edition Washington D.C. 
${ }^{11}$ Centers for Disease Control (2008). "Safe Water for the Community: A Guide for Establishing a Community-Based Safe Water System Program", http://www.ehproject.org/PDF/ehkm/cdcsafewater_community.pdf, Retrieved December 31, 2011.

${ }^{12}$ Maurice, Tax (2011). Personal Communication. www.BrightSpark.nl, Joure, Netherlands.

${ }^{13}$ Seattle University Engineers Without Borders USA (2011). http://www.su-ewb.org/manuals, Retrieved December 31, 2011.

${ }^{14}$ Lockwood, H., Smits, S., Schouten, T., Moriarty, P. (2010) "Providing Sustainable Water Services at Scale", IRC International Water and Sanitation Centre, p.1-10.

IRC International Water and Sanitation Centre, Press Release: IRC 